\title{
Discussion on Promise of Entrepreneurship as a Field of Research
}

\author{
Abdulsalam Jibril ${ }^{1}$, PhD, Ibrahim Mohammed Babbuli ${ }^{1}$ \\ ${ }^{I}$ Dept; of Business Administration, Adamawa State University, Mubi-Nigeria
}

*Corresponding Author: Abdulsalam Jibril, PhD, Ibrahim Mohammed Babbuli., Dept; of Business Administration, Adamawa State University, Mubi-Nigeria

\begin{abstract}
The paper aimed to explain the promise of entrepreneurship as a field of research. In entrepreneurship research, there are many disciplines primarily economics, management/business administration, sociology, psychology, economic and cultural anthropology, business history, strategy, marketing, finance, and geography representing a variety of research traditions, perspectives, and methods. The study is divides into four part, conceptual framework, previous study, results and recommendations. The study aimed at identifies the reasons why studying entrepreneurship is necessary as a field of research. This paper was examined using research articles, peer-reviewed, journals, books, empirical study, and other credible published materials by professional in the field of entrepreneurial studies, business, and history as well as other related fields. The study explores that field of entrepreneurship is concerned with discovering and exploitation of entrepreneurial opportunities. There are many recommendations such as researchers should give more priority and consider entrepreneurship as a field of research, as this will give them more knowledge on how to discover and exploit entrepreneurial opportunities lying within their country and even abroad.
\end{abstract}

Keywords: Entrepreneurship, Promise and Field of research

\section{INTRODUCTION}

It is now generally recognized that entrepreneurial activity is one of the primary drivers of industrial dynamism economic development and growth. Yet research on entrepreneurship is relatively recent and rapidly evolving. Entrepreneurship has developed in many sub-fields within several disciplinesprimarily economics, management/business administration, sociological, psychology, economic and cultural anthropology, business history, strategy, marketing, finance, and geography representing a variety of research traditions, perspectives and methods.

For the field of knowledge of entrepreneurship to be legitimized among other existing fields, it needs to have its own differentiated and recognized ontological and epistemological basis. To achieve this it has to start with theoretical discussions based on conceptual models taken from other disciplines and on empirical studies that prove and validate the new explanatory theoretical models. This process should result in a new articulated theory that integrates all the elements of the enterprising phenomenon and is recognized by colleagues from other fields of research. One indicator that this identity has been achieved is the existence of proposed questions, concepts and relations that are different from those posed in other fields of inquiry and that make it explicit that the problem proper to the field cannot be completely understood through the conceptual «lenses» of other fields. Then we will be able to recognize the existence of a new-field of knowledge: entrepreneurship.

Entrepreneurship research is relatively new as an academic field, but it has a long tradition. The term "entrepreneur" has been used in the French language since the twelfth century, but the feudal system dominating in Europe in the Middle Ages hampered the development of entrepreneurship and innovation. Gradually emerging cities became a breeding ground for entrepreneurship among the merchant class, especially in Italy, France, and Southern Germany (Landström, 2005).

It is imperative for the field of social science to have effectiveness, a conceptual framework that explains and forecasts a set of empirical phenomena not explained or predicted by conceptual frameworks already in existence in other fields. To date, the phenomenon of entrepreneurship has lacked such a conceptual frame work. Rather than explaining and predicting a unique set of empirical phenomena, entrepreneurship has become a broad label under which miscellaneous things of research 
is housed. What appears to constitute entrepreneurship research today is some aspect of the setting (e.g., small businesses or new firms), rather than a unique conceptual domain.

As a result, many people have had trouble identifying the distinctive contribution of the field to the broader domain of business studies, undermining the field's legitimacy. Moreover, the lack of a conceptual framework has precluded the development of an understanding of many important phenomena not adequately explained by other fields.

Moreover, this does not provide an adequate test of entrepreneurship, since entrepreneurship is concerned with the discovery and exploitation of profitable opportunities. A performance advantage over other firms is not a sufficient measure of entrepreneurial performance, because a performance advantage may be insufficient to compensate for the opportunity cost of other alternatives, a liquidity premium for time end capital, and a premium for uncertainty bearing (Westhead\& Wright, 2000).

Today the field of entrepreneurship is split between two different views on venture creation: the discovery versus creation view (Welsch, 2004). The focus of this paper is on whether or not Entrepreneurship is a research discipline, which is an additional debate in the field today. It is on this bases that this research was carried out in order to assess the promise of entrepreneurship is a field of study. It also tends to identify the reasons why studying entrepreneurship is necessary as a field of researchand to identify the different categories of entrepreneurial opportunities existing. The study is divides into four part, conceptual framework, previous study, results ,conclusion and recommendations.

\section{CONCEPTUAL FRAMEWORK}

The term entrepreneurship is derived from a French word "entrepreneur" meaning one who undertakes tasks in a production process. It could also be defined in terms of specific functions which the entrepreneur performs or in terms of characteristics or activities generally associated with the entrepreneur. The concept of entrepreneurship has been explained by various authors in various ways. However in all, the basic issues remain constant. For instance entrepreneurship has been defined as:

The willingness and the ability of an individual to seek out investment opportunities in an environment and be able to establish and run an enterprise successfully based on the identified opportunities (Ernst, and Young, 2009). What occurs when an individual develops a new venture or a new approach to an old business or idea or a unique way of giving the market place a product or service by using resources in a new way under conditions or risk (Hijzen, Upward and Wright, 2007).

A clear manifestation of effective manipulation of human intelligence as demonstrated in creative performance. It seeks to find out how best graduates can convert their education to intellectually productive ventures in order to bring out the best in an individual (Ilmakunnas, and Maliranta, 2003).

It involves risking financial, material and human resources in a new way in the course of creating a new business concept or opportunity within an existing firm (Salami, 2011). Creating and building something of value from practically nothing or creation and distribution of something of value and of benefits to individuals, groups, organizations and society (Timmons and Spinelli, 2004).

The entrepreneurial function implies the discovery, assessment and exploitation of opportunities, in other words, new products, services or production processes; new strategies and organizational forms and new markets for products and inputs that did not previously exist (Shane and Venkataraman, 2000). The entrepreneurial opportunity is an unexpected and as yet unvalued economic opportunity.

Entrepreneurial opportunities exist because different agents have differing ideas on the relative value of resources or when resources are turned from inputs into outputs. The theory of the entrepreneur focuses on the heterogeneity of beliefs about the value of resources (Alvarez and Busenitz, 2001).

Entrepreneurship -the entrepreneurial function- can be conceptualized as the discovery of opportunities and the subsequent creation of new economic activity, often via the creation of a new organization (Reynolds, 2005).

Carlssonet. al. (2009) defines that domain of entrepreneurship research as follows: Entrepreneurship refers primarily to an economic function that is carried out by individuals, entrepreneurs, acting independently or with an organization, to perceive and create new opportunities and to introduce their ideas into the market, under uncertainty, by making decisions about location, product design, resource 
use, institutions, and reward systems. The entrepreneurial activity and entrepreneurial ventures are influence by the socioeconomic environment and result ultimately in economic environment and result ultimately in economic growth and human welfare.

\section{LITERATURE REVIEW}

In his early review of the scientific discourse on entrepreneurship, Marc Casson (1982) concluded "The essence of entrepreneurship is being different". Why then, may we ask, is so much of entrepreneurship research so very similar? Research surveys of the field by, among others, Landström, et. al. (2012) suggests that one reason why entrepreneurship research is becoming more homogeneous stems from the maturation and institutionalization of entrepreneurship as a research field.

Two important exceptions in entrepreneurship research are the recent literature reviews by Landstrom (2012) and Aldrich (2011) who outlines the historical development of fields of entrepreneurship, showing how entrepreneurship research has become both increasingly cumulative and institutionalized. We will not discuss the potential pros and cons with this institutionalization beyond noting that it has been successful in attracting many new scholars to an increasingly global academic field.

As some authors have argued (e.g. Baker and Pollock, 2007), one reason for the institutionalization of entrepreneurship research is that the research questions and tools by and large stem from the research areas of strategic management and organization theory. Many entrepreneurship scholars have their training in these areas, and to a lesser extent in the disciplines of economics, sociology, or psychology (Busenitz et al., 2003). But since entrepreneurship research is primarily conducted at business schools, strategic management and organization theory predominate (Baker and Pollock, 2007).

In addition these areas come with their own traditions, theories, value-laded assumptions, and methodological canons. For example, many have lamented the lack of process-oriented studies in entrepreneurship, despite the obvious insight that most of entrepreneurship can better be described as a process rather than a choice, a single event, or a fixed unit of analysis such as an individual or a new firm (Van de Ven and Engleman, 2004).

\section{THE IMPERATIVE OF ENTREPRENEURSHIP AS A FIELD OF RESEARCH}

Many academics ask themselves, implicitly or explicitly, why we should study entrepreneurship? There are many ways to answer this question, but in synthesis, we can summarize it from three points of view: economic, social and academic. The Global Entrepreneurship Monitor (GEM; Reynolds, Bygrave, \&Autio, 2004) describes entrepreneurship as a «world-wide phenomenon» that is on the increase. e.g. In the 1990s there was important activity in the creation of new businesses, mainly in transition economies, where activity in the private sector was relatively new. In Spain there was a resurgence of entrepreneurship at the end of the 90s, coinciding with the new millennium (Sánchez, 2010). Nine out of every 100 individuals of working age around the world are involved in entrepreneurship, with approximately 300 million presently involved in the creation stage of a new business venture (Reynolds, et al., 2004).

Entrepreneurship is also an important source of employment for women and there has been significant growth worldwide in women's self-employment (Coughlin \& Thomas, 2002). A dominant trend in the 21 st century is likely to be ethnic entrepreneurship, because of the free market, free circulation of persons and the development of infrastructures (Morris, Schindehutte, \&Lesser, 2002). In short, entrepreneurship has come to be perceived as an engine of economic and social development throughout the World. As Lazear (2002) points out, «the entrepreneur is the single most important player in a modern economy». To this social and economic interest we must add the interest it arouses in the academic world.

There are four key reasons why entrepreneurship knowledge is important these includes: (a) enterprising human activity; (b) the assembly of unique bundles of resources, identification of market opportunities, and/or utilisation of innovative capabilities; (c) the significance of the business and wider environments, and (d) the creation of value. These are now introduced in turn.

\subsection{Enterprising Human Activity}

Returning to the earliest conceptualizations of the entrepreneur as the person in business, undertaking or projecting into their future is to know their customers or the markets. (Defoe, 
2001) stated that, the entrepreneur "cannot evade the law of the market. He can succeed only by best serving the consumers. His profit depends on the approval of his conduct by the consumers." However, entrepreneurship need not be defined by the formation of a new enterprise, for example an entrepreneur may licence an idea or concept to another firm (Shane, 2003).

A more appropriate conception is that from Stevenson and Jarillo (1990), who proposed entrepreneurship to be the study of why, how and what happens when entrepreneurs act. Understanding the organising process is one of the necessary elements of entrepreneurship: "Entrepreneurs create new organizations through a dynamic process that involves such activities as obtaining equipment, establishing production processes, attracting employees and setting up legal entities" (Shane, 2003)

\subsection{Leveraging Creativity, Innovation and/or Opportunity:}

To organise the human activities, the analysis now explores the nature of entrepreneurial activities, organising the analysis according to resources, capabilities and markets introduced above. Resources include access to: (i) physical capital such as property or plant and equipment, (ii) financial capital such as debt finance or equity, and (iii) intangible resources such as intellectual property or technology. These resources can typically be bought and sold by firms or individuals. Changes in these resources can have dramatic implications for firm performance, with changes in these resources typically resulting from (i) creative inventions or discovery, or (ii) unusual and unique combinations of these resources such as venture capital funding. Entrepreneurial activity in „creative resources ${ }^{\text {ee }}$ is supported by the, entrepreneurial community"e, which includes venture capitalists, debt providers, and intellectual property lawyers. Capabilities include the human and social expertise required to leverage a firms resources to market. In an entrepreneurial context, these innovative capabilities include the perception and recognition of a match between creative resources and market opportunities. This may include novel and skilled capabilities as well as unique or unusual social networks and connections (Ardichvili, Cardozo, \&Sourav, 2003).

The perception and discovery of market opportunity is an important focus of entrepreneurship research (Gaglio\& Katz, 2001) as it is one of the most important abilities of successful entrepreneurs and is one of the core intellectual questions for researchers (Gaglio\& Katz, 2001). Market entry need not result in the founding of a new firm or the use of market mechanisms, however "it does require the creation of a new way of exploiting the opportunity (organizing) that did not previously exist" (Shane, 2003).

\subsection{Operating in Changing \& Uncertain Environment}

This disruptive entrepreneurship should not be interpreted as destroying and replacing industries with new ones but as bringing change to the market to a greater or lesser degree. Given the different ways entrepreneurs fulfil their role in the market; it can be argued that Kirznerian and Schumpeterian entrepreneurs could both work simultaneously, as the former engage in arbitrage and the latter in innovation. Cultural impacts, widely considered in Entrepreneurship literature, are a narrow consideration of the entire environment affecting entrepreneurial activity (Ardichvili, Cardozo, et al., 2003).

These wider environmental impacts include the natural, social and cultural environments. One popular framework for analysing these impacts is the PESTLN framework: political, economic, socio-cultural, technological, legal and the natural environments. These environmental impacts are typically outside the control of the entrepreneur, and outside the control of the particular industry participants. In addition to the environmental factors, the business environment will impact entrepreneurial activity. These factors could include industry structures, impacted by bargaining power, threats and competitive rivalry. Policy makers can have significant impact on these industry conditions. 


\subsection{The Creation of Value}

The entrepreneur creates extraordinary value in the sense that their entrepreneurial activity results in sustained competitive advantage and super-normal returns for a number of parties. Innovators (entrepreneurs) enjoy "temporary monopoly power". When imitators see a signal that above-normal gains can be made, they enter and erode the entrepreneurse profit and return the market to equilibrium. As reviewed in Walker and Brown (2004), entrepreneurs have been shown to value a number of non-financial measures of success, including autonomy, job satisfaction, the ability to balance work and family. These are all subjectively and personally defined, however can have a major impact on the decisions and exchanges involved in the creation and exploitation of opportunities. Similarly, at the firm and national levels, value can include economic, social or cultural significance. Economic value would be considered in relation to an activity ${ }^{\text {ee }}$ pecuniary, or dollar, output and include concepts such as economic growth, productivity growth etc. Alternatively, an entrepreneurial undertaking can create social value such as personal relationships, poverty reduction, enhancement of job satisfaction or the creation of better jobs. A third value that could be considered in addition to these two extrinsic values is cultural value, which relates to the development of creative or cultural capital. Entrepreneurial activity results in more than self-employment, and may include returns to employees, shareholders, society (through taxes and other payments), other members of the entrepreneurial community (such as financiers and advisors) and customers (through superior value propositions). Entrepreneurial value creation and exchange can form the basis of understanding entrepreneurial activity and its impacts at both a microlevel (individual, group) and macrolevel (organisation theory, strategic management, and policylevel).

\section{ENTREPRENEURShiP AS A FIELd AS KNOWLEDGE: StATE OF THE ART}

According to different literature reviews based on bibliometric studies (Busenitz et al., 2003; Murphy, Liao, \&Welsch, 2006) we can group the different theories that are being developed into three approaches or theoretical perspectives - economic, psychological and sociological - . In our view, the field of entrepreneurship would be located at the intersection of these three perspectives (Figure 1). The limits imposed by the scope of this article oblige us to resort to a succinct description of each of them.

\subsection{The Economic Perspective}

The creation of companies as a factor of economic development depends, according to Schumpeter, on the entrepreneur-innovation relationship. The entrepreneur is the agent who introduces the innovations, creates the change, and causes an adjustment in the economic system (Theory of economic development by Schumpeter). Entrepreneurs take basic innovations and transform them into economic innovations. Other authors have pointed out that all individuals have the same aptitude for being an entrepreneur or a worker, and that the decision to become an entrepreneur is taken exclusively on the basis of an inclination or an aversion to risk (theory of occupational choice under uncertainty).

Acs and Varga (2005) try to make up for the defects of these first spillover models, because they do not explain what the processes are that facilitate the learning and the dissemination of knowledge or the characteristics of the territorial unit or area that are relevant in the exchange of knowledge among firms. Recent research studies show that the learning processes, the dissemination of knowledge, and the spillover effect occur through the following factors (Veciana, 2006): human capital, social mobility, social networks, and business or enterprising capital, the latter being the essential element of the theory.

\subsection{The Psychological Perspective}

This outlook attempts to explain the characteristics, attributes, or traits that make certain individuals become entrepreneurs, as well as the specific characteristics of successful entrepreneurs as opposed to less successful ones. Two large orientations or trends can be identified within this perspective. 


\subsubsection{Theory of personality traits.}

This is based on the supposition that entrepreneurs have personality traits that are different from those of non-entrepreneurs. Although a classic in the psychology of entrepreneurship, this approach is polemical. Currently there is disagreement in the literature as to whether personality is a useful construct in entrepreneurship research (Sánchez, 2010).

For example, some studies have demonstrated that the personality characteristics of entrepreneurs do not differ reliably from those of non-entrepreneurs and only account for a small percentage of the variance in entrepreneurial success (Hisrich, 2000). Meta analytic research has revealed a slight positive relationship between autonomy, internal locus of control and risk-taking propensity and the creation of business ventures and success, and a moderately positive relationship between the latter and innovation, need for achievement and self-efficacy. The risk-taking propensity has a weak relationship with both result variables and self-efficacy is more strongly related to success (Rauch \&Frese, 2007).

Nevertheless, it is possible that the role of personality in entrepreneurship may not have been considered in past research owing to methodological and design limitations (Hisrich, Langan Fox, \& Grant, 2007).

\subsubsection{Cognitive Theory}

Enterprising cognition can be defined as the «knowledge structures that people use to make assessments, judgments or decisions involving opportunity evaluation, venture, creation and growth» (Mitchell, Busenitz, Lant, McDougall, Morse, \& Smith, 2002; Sánchez, 2009).

Although the research in this field is still in its early stages, the work to date suggests that entrepreneurs seem to make cognitive leaps regarding potential opportunities before they can be rationally and systematically evaluated (Busenitz et al., 2003).

Entrepreneurs may have a special ability to identify opportunities where other people do not see them. If the cognitive processes of entrepreneurs are different from those of non-entrepreneurs, then this would affect how they assess opportunities, as well as the risk perception this entails. The recent interest in opportunity recognition (the cognitive processes through which opportunities are identified) has undergone an important theoretical development in the literature on entrepreneurship (Baron, 2006).

The recognition of opportunities has been attributed to active search enterprising alert (Gaglio\& Katz, 2001), previous knowledge and cognitive mechanisms (Shane \&Venkataraman, 2000), ability, efficacy, motivation and desirability and more recently, to recognizing a pattern or «connecting the dots» (Baron, 2006). Nevertheless, despite the plethora of theoretical works, the study of opportunity recognition has yet to be explored empirically (Hisrich et al., 2007).

\subsection{The Sociological Perspective}

The theories we include in this perspective have in common the supposition that the decision to become an entrepreneur is conditioned by external factors or the social context. That is, it is sociocultural factors, or the institutional framework, that determines entrepreneurship at a specific time and place. From the sociological perspective there are also authors who defend that the enterprising function forms part of and develops in a network of social relations (network theory). There are interesting contributions that try to explain the role of social networks in the enterprising process and attempts have been made to set the foundations of a theory of entrepreneurship based on the network approach (Hoang and Antoncic, 2003).

Perhaps the theory currently providing the most coherent theoretical framework for studying the influence of environmental factors is the institutional theory. This theory is based on the supposition that institutions make the rules of the game, the devised and imposed restrictive forces - both formal and informal - that configure and determine human interaction. Only a few studies have been done within this theoretical framework and only isolated factors have been studied. Nonetheless, many of these studies show the importance of these environmental or institutional factors (Busenitz et al., 2003). 


\section{MethodologY}

This paper was examined using research articles, peer-reviewed, journals, books, empirical study, and other credible published materials by professional in the field of entrepreneurial studies, business, and history as well as other related fields for the proper definition for term entrepreneurship as well who is an entrepreneur and importance of entrepreneurship as a field of studies.

\section{FINDINGS OF THE RESEARCH}

- The field of entrepreneurship research focuses mainly on new enterprise and its roles in furthering economic progress.

- It also shows that field of entrepreneurship is concerned with discovering and exploitation of entrepreneurial opportunities.

- Finding shows that entrepreneurship as a field of research helps individuals to study and understand the concept, organizing process and necessary elements of entrepreneurship.

\section{CONCLUSiON}

Opportunity for entrepreneurial profit might exist, an individual can earn this profit only if he or she recognizes that the opportunity exists and has value. Given that an asymmetry of beliefs is a precondition for the existence of entrepreneurial opportunities, all opportunities must not be obvious to everyone all of the time. At any point in time, only some subset of the population will discover a given opportunity.

This paper was able conclude that entrepreneurship as a field of research has great impact of new firm formation and firm dynamics on economic and social variables such as economic development, technological change, economic growth, productivity, wealth creation and inequality. But there seems to be a need for a more dynamic theory in which there is room for human actors, including entrepreneurs, who are boundedly rational and who act under genuine uncertainty. This appears promising for the study of entrepreneurship; studies in this area are beginning to emerge and necessary for the survival of every nation.

\section{RECOMMENDATIONS}

- It therefore, recommended that field of entrepreneurship research should giving more attention to encompass all institution of learning because of its roles in providing ideas of new enterprises and economic progress in any country

- Government and researcher should embrace entrepreneurship as a field of research because studying entrepreneurship as a course has helps many individuals to study and understand the concept of entrepreneur, organising process and necessary elements of entrepreneurship.

- Entrepreneurship as a field of research should be consider as a bedrock and life circle of every society because entrepreneurship as a field of research help individual to acquire the knowledge of innovative capabilities, the perception and recognition of a match between creative resources and market opportunities.

\section{REFERENCES}

[1] Ács, Z., \& Varga, A. (2005). Entrepreneurship, agglomeration and technological change. Small Business Economics, Springer, 24(3), 323-334.

[2] Aldrich, H., \& Zimmer, C. (2011).Entrepreneurship through social networks, In D. Sexton \& H. Smilor (Eds).The art and science of entrepreneurship.3-23. Cambridge, MA: Bollinger.

[3] Alvarez, S. A. \&Busenitz, L. W. (2001). The Entrepreneurship of Resource-Based Theory. Journal of Management, 27, 755-775.

[4] Ardichvili, A., Cardozo, R. \&Sourav, R. (2003).A Theory of Entrepreneurial Opportunity Identification and Development.Journal of Business Venturing, 18: 105-23.

[5] Baker, T., \& Pollock, T. G. (2007).Making the marriage work: The benefits of strategy's takeover of entrepreneurship for strategic organization.Strategic Organization, 5(3): 297-312. 
[6] Baron, R. A. (2006).Opportunity recognition as pattern recognition: How entrepreneurs «connect the dots» to identify new business opportunities. Academy of Management Perspectives, 20, 104-119.

[7] Busenitz, L., \& Barney, J. (1997). Differences between entrepreneurs and managers in large organizations: Biases and heuristics in strategic decision-making. Journal of Business Venturing, 12: 9-30.

[8] Busenitz, L.W., West III, G.P., Shepherd, D., Nelson, T., Chandler, G.N., \&Zacharakis, A. (2003). Entrepreneurship research in emergence: Past trends and future directions. Journal of Management, 29(3), 285-308.

[9] Carlsson, B., Acs, Z. J., Audretsch, D. B., \&Braunerhjelm, P. (2009). Knowledge creation, entrepreneurship, and economic growth: A historical review. . Industrial and Corporate Change, 11931229.

[10] Coughlin, J. H., \& Thomas, A. R. (2002).The Rise of Women Entrepreneurs: People, processes and global trends. Westport, CT: Quorum Books.

[11] Defoe, D. (2001). An Essay on Projects, Project Gutenberg eTexts: Project Gutenberg eTexts.

[12] Ernst, O. and Young, E. (2009). "Entrepreneurship and Innovation: The Keys to Global Economic Recovery, White Paper Report. Provide Initial and page.

[13] Gaglio, C M \& J Katz. (2001). The Psychological Basis of Opportunity Identification: Entrepreneurial Alertness. The Journal of Small Business Economics, 16: 95-111.

[14] Gaglio, C.M., \& Katz, J. (2001). The psychological basis of opportunity identification: Entrepreneurial alertness. Journal of Small Business Economics, 16, 11-95.

[15] Hijzen, A., R. Upward and Wright, P. (2007), Job Creation, Job Destruction and the Role of Small Firms: Firm-Level Evidence for the UK, GEP Discussion Papers 07/01, University of Nottingham.

[16] Hisrich, R. D. (2000). Marketing.(2nd edition).Hauppauge, NY: Barrons.

[17] Hisrich, R., Langan-Fox, J., \& Grant, S. (2007). Entrepreneurship research and practice: A call to action for psychology. American Psychologist, 62(6), 575-589.

[18] Hoang, H., \&Antoncic, B. (2003). Network-based research in entrepreneurship: A critical review. Journal of Business Venturing, Elsevier, March, 18(2), 165-187.

[19] Ilmakunnas, P. and Maliranta, M. (2003). The turnover of jobs and workers in a deep recession: Evidence from the Finnish business sector, International Journal of Manpower, 24, 216-46.

[20] Landström, H. (2005). Pioneers in Entrepreneurship and Small Business Research. New York: Springer.

[21] Lazear, E.P. (2002). Entrepreneurship, National Bureau of Economic Research, Cambridge, MA, working paper no. 9109.

[22] Mitchell, R. K., Busenitz, L., Lant, T., McDougall, P. P., Morse, E. A., \& Smith, B. (2002). Toward a theory of entrepreneurial cognition: Rethinking the people side of entrepreneurship research. Entrepreneurship Theory \& Practice, 27, 93-104.

[23] Morris, M. H., Schindehutte, M., \& Lesser, J. (2002). Ethnic entrepreneurship: Do values matter? New England Journal of Entrepreneurship, 5(2), 35- 46.

[24] Murphy, P.J., Liao, J.W., \&Welsch, H.P. (2006).A conceptual history of entrepreneurial thought.Journal of Management History, 12(1), 12- 35.

[25] Reynolds, P. (2005). Entrepreneurship Processes and Small Business Management, Ilaro, Nigeria.

[26] Reynolds, P., Bygrave, W., \&Autio, E. (2004).Global Entrepreneurship Monitor, GEM. BabsonCollege, LondonBusinessSchool: Ewing Marion Kauffman Foundation.

[27] Salami, C. G. E. (2011).Entrepreneurial Interventionism and Challenges of Youth Unemployment in Nigeria, Global Journal of Management and Business Research.Vol. 11, Issue 7, Version 1.0 July 2011. Global Journals Inc. (USA).

[28] Sánchez, J. C. (2009). Social learning and entrepreneurial intentions: A comparative study between Mexico, Spain and Portugal. RevistaLatinoamericana de Psicología, 41(1), 107-117.

[29] Sánchez, J. C. (2010). Evaluation of entrepreneurial personality: Factorial validity of entrepreneurial orientation questionnaire (COE). RevistaLatinoamericana de Psicología, 42(1), 32-52.

[30] Sánchez, J. C. (2010). University training for entrepreneurial competencies: Its impact on intention of venture creation. International Entrepreneurship and Management Journal, April, 1-16.

[31] Shane, S. (2002). The Foundations of Entrepreneurship, Vols. ii \& iii.Cheltenham: Edward Elgar.

[32] Shane, S. 2003. A General Theory of Entrepreneurship: The Individual-Opportunity Nexus. Cheltenham, UK: Edward Elgar.

[33] Stevenson, H H\& J C Jarillo. 1990. A Paradigm of Entrepreneurship: Entrepreneurial Management. Strategic Management Journal, 11: 17-27. 
[34] Timmons, J. A. \&Spinelli, S. (2004). New Venture Creation: Entrepreneurship for the 21st Century. Boston: McGraw Hill Irwin.

[35] Van de Ven, A. H. and Engleman, G. (2004).A framework for understanding the emergence of new industries'.Research on Technological Innovation, Management and Policy 4: 192-225.

[36] Veciana, J. M. (2007). Entrepreneurship as a scientific research programme. In A. Cuervo, D. Ribeiro\& S. Roig (Eds.), Entrepreneurship: Concepts, theory and perspective (pp. 23-71). Heidelberg: Springer.

[37] Welsch, H. P. (ed.), ( 2004). Entrepreneurship: The Way Ahead. New York: Routledge.

[38] Westhead, P. and Wright, M. (eds.), (2000). Advances in Entrepreneurship, Vol. I. Cheltenham, UK: Elgar.

\section{AUTHOR'S BIOGRAPHY}

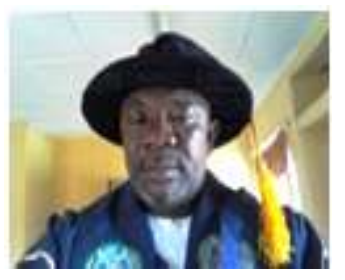

Professor Abdulsalam Jibril is a Professor of Entrepreneurial Marketing at Adamawa State University, Mubi Nigeria.

He holds B.Sc Business Administration (1998), Master of Business Administration(2006) and $\mathrm{PhD}$ in Business Administration from Ahmadu Bello University, Zaria. The University of Maiduguri, Nigeria and Trinity College,(Now American Trinity University, California) (2009) respectively. He taught in Ramat Polytechnic, Maiduguri Nigeria for (8) years and moved to ADSU, Mubi since 2010.He was at Nasarawa State University Keffi in 2014 as Associate Professor in Entrepreneurship till 2016.He is now back to ADSU, Mubi where he was assessed as a Professor of Entrepreneurial Marketing.

Prof.Jibril has supervised both undergraduates and postgraduates students. He has many published papers to his credit.His research areas are Marketing and Entrepreneurship.He is presently the Director of Entrepreneurship development Centre at ADSU, Mubi Nigeria.

Citation: Abdulsalam Jibril, PhD, Ibrahim Mohammed Babbuli. "Discussion on Promise of Entrepreneurship as a Field of Research "International Journal of Managerial Studies and Research (IJMSR), vol 5, no. 12, 2017, pp. 46-54. doi:http://dx.doi.org/10.20431/2349-0349.0512006.

Copyright: (1) 2017 Authors. This is an open-access article distributed under the terms of the Creative Commons Attribution License, which permits unrestricted use, distribution, and reproduction in any medium, provided the original author and source are credited. 